\title{
Correction to: Using Constitutive Activity to Define Appropriate High-Throughput Screening Assays for Orphan G Protein-Coupled Receptors
}

\author{
Tony Ngo, James L.J. Coleman, and Nicola J. Smith
}

\section{Correction to:}

Chapter 7 in: Duarte Miguel F. Prazeres and Sofia Aires M. Martins (eds.), G Protein-Coupled Receptor Screening Assays, Methods in Molecular Biology, vol. 1272, https://doi.org/10.1007/978-1-4939-2336-6_7

With awareness of the cloning error that invalidated some of the recommendations made with respect to the CRE-Luciferase Reporter assay described in this chapter, the advice provided in Note 16, and supported by data in Figure 7.3, is disregarded. No other aspect of the protocol or recommendations has been affected by this mistake. 